Article

\title{
Phytochemicals and Estrogen-Receptor Agonists from the Aerial Parts of Liriope platyphylla
}

\author{
Yu-Chi Tsai 1,†, Chia-Chun Hsu ${ }^{1,2, \dagger}$, Mohamed El-Shazly 1,3, Shang-Yu Chiang 1, \\ Chau-Chung Wu ${ }^{4}$, Chin-Chung Wu ${ }^{1}$, Wan-Chun Lai ${ }^{1}$, Ming-Hong Yen ${ }^{1}$, \\ Yang-Chang Wu ${ }^{1,5,6,7, *}$ and Fang-Rong Chang $1,8,9,10, *$
}

1 Graduate Institute of Natural Products, Kaohsiung Medical University, Kaohsiung 807, Taiwan; E-Mails: yuchi0713@gmail.com (Y.-C.T.); chia6494@yahoo.com.tw (C.-C.H.); elshazly444@googlemail.com (M.E.-S.); rhytlise@gmail.com (S.-Y.C.); ccwu@kmu.edu.tw (C.-C.W.); stellapple7@gmail.com (W.-C.L.); yen@kmu.edu.tw (M.-H.Y.)

2 Department of Laboratory Medicine, Paochien Care Cooperation Paochien Hospital, Pingtung 900, Taiwan

3 Department of Pharmacognosy and Natural Products Chemistry, Faculty of Pharmacy, Ain-Shams University, Organization of African Unity Street, Abassia, Cairo 11566, Egypt

4 Department of Internal Medicine, National Taiwan University Hospital, Taipei 100, Taiwan; E-Mail: chauchungwu@ntu.edu.tw

5 Chinese Medicine Research and Development Center, China Medical University Hospital, Taichung 404, Taiwan

6 School of Chinese Medicine, College of Chinese Medicine, China Medical University, Taichung 404, Taiwan

7 Center for Molecular Medicine, China Medical University Hospital, Taichung 404, Taiwan

8 Cancer Center, Kaohsiung Medical University Hospital, Kaohsiung 807, Taiwan

9 Research Center for Natural Product and New Drug, Kaohsiung Medical University, Kaohsiung 807, Taiwan

10 Department of Marine Biotechnology and Resources, National Sun Yat-sen University, Kaohsiung 807, Taiwan

$\dagger$ These authors contributed equally to this work.

* Authors to whom correspondence should be addressed;

E-Mails: yachwu@mail.cmu.edu.tw (Y.-C.W.); aaronfrc@kmu.edu.tw (F.-R.C.); Tel.: +886-7-3121101 (ext. 2162) (F.-R.C.); Fax: +886-7-3114773 (F.-R.C.).

Academic Editor: Derek J. McPhee 


\begin{abstract}
One new benzofuran, (2R)-(2',4'-dihydroxybenzyl)-6,7-methylenedioxy-2,3dihydrobenzofuran (1), one new phenylisocoumarin, 3-(2'-hydroxyphenyl)-6,8-dihydroxy7-methoxy-isocoumarin (2), and one new benzofuroisocoumarin, platyphyllarin C (3), were isolated from the ethanolic extract of Liriope platyphylla aerial parts, along with seventeen known compounds. The structures of the isolates were established by spectroscopic analysis and comparison with the literature data. The results indicated that structures 1-3 are uncommon in Nature. Benzofuroisocoumarin 4, flavonoids 9, 10, and 13-15, and homoisoflavonoids 19 and 20 exhibited significant binding activity to estrogen-receptor $\alpha$ and/or $\beta$ as demonstrated by the SEAP reporter assay system in an MCF-7 cell-line.
\end{abstract}

Keywords: Liliaceae; Liriope platyphylla; benzofuroisocoumarin; homoisoflavonoid; estrogenic activity; estrogen-receptor agonist

\title{
1. Introduction
}

The aerial parts of Liriope platyphylla Wang et Tang (Liliaceae) are used in Asia as nutrients and food supplement [1,2]. They possess reproductive tonic, antitussive, expectorant, and demulcent effects [1]. Phytochemical investigation of Liriope sp. indicated that steroidal compounds are the major class of secondary metabolites in this genus [3]. Other classes of secondary metabolites isolated from this genus included homoisoflavonoids [4], benzofurans [5], anthocyanins [1], amides [4], and sesquiterpenoids [6]. Plants belonging to the genus Liriope were found to possess hepatoprotective [7], antibacterial [8], anti-inflammatory [5], cytotoxic [9], antidiabetic [10], and neuroprotective [11] activities.

Recently, we reported that certain components isolated from L. platyphylla roots showed significant anti-platelet and estrogenic effects [12]. In our continuing investigation to search for novel phytoestrogenic resources, different plants used in Asian folk medicines were assayed for their estrogenic activity. Among the examined plants, the ethanolic extract of L. platyphylla aerial parts was found to be significantly active in the transgenic Arabidopsis pER8:GUS assay [12] (Arabidopsis pER8:GUS possessing a human estrogen ER $\alpha$ receptor activating assay system) at $12.5 \mu \mathrm{g} / \mathrm{mL}$. Therefore, the extract was selected for further phytochemical and pharmacological investigation. In the current investigation, the isolation and structure elucidation of secondary metabolites isolated from L. platyphylla aerial parts were discussed. The binding activity of the isolates to the estrogen-receptors (ER) $\alpha$ and/or $\beta$ in a SEAP reporter assay system using the MCF-7 cell-line was also investigated.

\section{Results and Discussion}

\subsection{Structural Elucidation of the Isolated Compounds}

The ethanolic extract of L. platyphylla aerial parts was selected for further investigation and subsequently partitioned with $n$-hexane, ethyl acetate (EtOAc), $n$ - $\mathrm{BuOH}$, and $\mathrm{H}_{2} \mathrm{O}$ to yield four fractions. 
The bioassay-guided isolation of the most active (EtOAc) fraction led to the purification of one new 2-benzyl-2,3-dihydrobenzofuran derivative, (2R)-(2',4'-dihydroxybenzyl)-6,7-methylenedioxy-2,3dihydrobenzofuran (1), one new phenylisocoumarin derivative, 3-(2'-hydroxyphenyl)-6,8-dihydroxy-7methoxy-isocoumarin (2), and one new benzofuroisocoumarin derivative, platyphyllarin C (3), along with seventeen known compounds (Figure 1). The known compounds were identified as (+)-platyphyllarin A (4) [12], (Z)-3-hexenyl- $\beta$-D-glucopyranoside (5) [13], 4,2',4'-trihydroxychalcone (6) [14], liquiritigenin (7) [15], diosmetin (8) [16], kaempferol (9) [17], 3-O-methylquercetin (10) [18], 3,3'-O-dimethylquercetin (11) [19], 3,4'-O-dimethylquercetin (12) [18], 6- $C$-methylquercetin-3-methyl ether (13) [20], kaempferol-3-O-glucoside (14) [21], quercetin-3-O-glucoside (15) [22], isorhamnetin 3-O-glucoside (16) [23], vanillin (17) [12], disporopsin (18) [24], 3-(2',4'-dihydroxybenzyl)-5,7-dihydroxy6-methylchroman-4-one (19) [12], and 3-(2',4'-dihydroxy-benzyl)-5,7-dihydroxy-6-methylchroman-4one (20) [12] by spectroscopic analysis and comparison with the reported physical data.
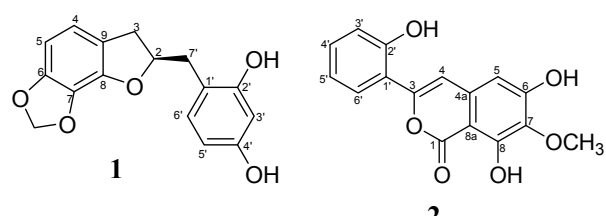

2

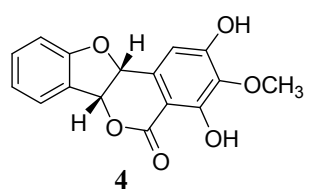

$\mathrm{HO}$

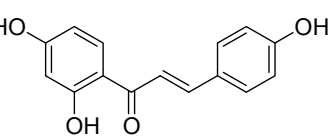

6

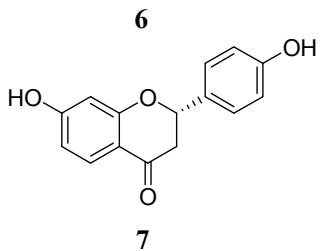

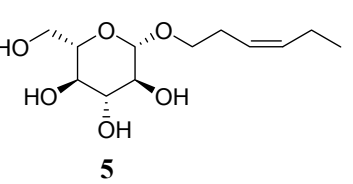
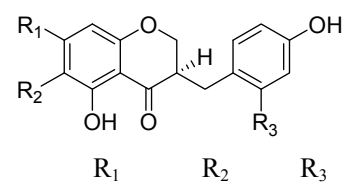

$18 \mathrm{OH} \quad \mathrm{H} \quad \mathrm{OH}$

$19 \mathrm{OH} \quad \mathrm{CH}_{3} \quad \mathrm{H}$

$20 \mathrm{OH}-\mathrm{CH}_{3}-\mathrm{OH}$

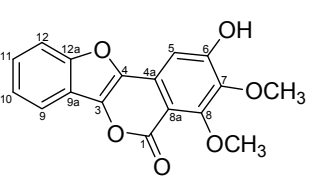

3

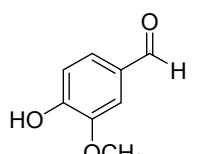

17
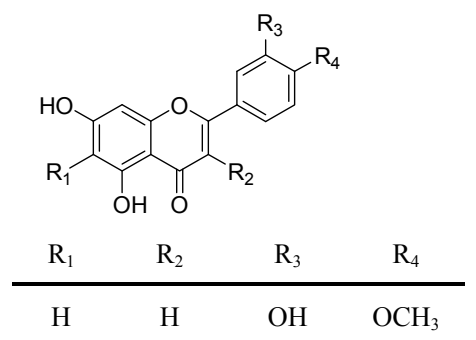

$9 \begin{array}{lllll}\mathrm{H} & \mathrm{OH} & \mathrm{H} & \mathrm{OH}\end{array}$

$10 \mathrm{H} \quad \mathrm{OCH}_{3} \quad \mathrm{OH} \quad \mathrm{OH}$

$11 \mathrm{H} \quad \mathrm{OCH}_{3} \quad \mathrm{OH} \quad \mathrm{OCH}_{3}$

$12 \mathrm{H} \quad \mathrm{OCH}_{3} \quad \mathrm{OCH}_{3} \quad \mathrm{OH}$

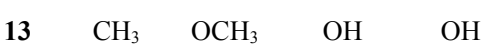

$14 \mathrm{H} \quad$ OGlu $\quad \mathrm{H} \quad \mathrm{OH}$

15 H $\quad$ OGlu $\quad \mathrm{OH} \quad \mathrm{OH}$

$16 \mathrm{H}$ OGlu $\mathrm{OCH}_{3} \quad \mathrm{OH}$

Figure 1. Chemical structures of compounds 1-21 isolated from the aerial parts of L. platyphylla.

Compound 1 was isolated as a light-yellow amorphous powder. The molecular formula was calculated as $\mathrm{C}_{16} \mathrm{H}_{14} \mathrm{O}_{5}$ from the analysis of its HRESIMS $\left(\mathrm{m} / \mathrm{z} 309.07307[\mathrm{M}+\mathrm{Na}]^{+}\right.$, calcd. for 309.07334), indicating ten degrees of unsaturation. The IR spectrum indicated the presence of hydroxy $\left(3397 \mathrm{~cm}^{-1}\right)$ and aromatic (1619 and $1600 \mathrm{~cm}^{-1}$ ) functionalities. The ${ }^{13} \mathrm{C}-\mathrm{NMR}$ and DEPT experiments suggested the presence of sixteen carbons, including three methylenes, six methines, five oxygenated aromatic carbons, and two $\mathrm{sp}^{2}$ quaternary carbons (Table 1). All protons and the corresponding carbons in $\mathbf{1}$ were assigned using coupling constant calculations and 2D NMR spectroscopic analysis. An oxymethine $\left(\delta_{\mathrm{H}}\right.$ $\left.5.08, \delta_{\mathrm{C}} 86.5, \mathrm{CH}-2\right)$, two methylenes $\left(\delta_{\mathrm{H}} 2.90,3.04, \delta_{\mathrm{C}} 35.2, \mathrm{CH}_{2}-3 ; \delta_{\mathrm{H}} 2.81,3.04, \delta_{\mathrm{C}} 36.6, \mathrm{CH}_{2}-7{ }^{\prime}\right)$, a 1,2,3,4-tetrasubstituted aromatic ring $\left(\delta_{\mathrm{H}} 6.59, \mathrm{~d}, J=7.6 ; \delta_{\mathrm{C}} 117.9, \mathrm{CH}-4 ; \delta_{\mathrm{H}} 6.32, \mathrm{~d}, J=7.6 ; \delta_{\mathrm{C}} 101.6\right.$, $\mathrm{CH}-5)$, a 1,2,4-trisubstituted aromatic ring $\left(\delta_{\mathrm{H}} 6.29, \mathrm{~d}, J=2.4 ; \delta_{\mathrm{C}} 103.4, \mathrm{CH}-3\right.$ '; $\delta_{\mathrm{H}} 6.23, \mathrm{dd}, J=8.4,2.4$; $\left.\delta_{\mathrm{C}} 107.4, \mathrm{CH}-5 ' ; \delta_{\mathrm{H}} 6.92, \mathrm{~d}, J=8.4 ; \delta_{\mathrm{C}} 132.8, \mathrm{CH}-6 '\right)$, and a methylenedioxy $\left(\delta_{\mathrm{H}} 5.86,2 \mathrm{H}, \delta_{\mathrm{C}} 102.3\right)$ 
were observed (Table 1). A 2,3-dihydrobenzofuran moiety was suggested by the COSY cross peak between $\mathrm{H}-2 / \mathrm{H}-3$.

Table 1. ${ }^{1} \mathrm{H}$ and ${ }^{13} \mathrm{C}-\mathrm{NMR}$ spectroscopic data of compounds $\mathbf{1}-\mathbf{3}(\delta$ in ppm, $J$ in $\mathrm{Hz}){ }^{\text {a }}$.

\begin{tabular}{|c|c|c|c|c|c|c|}
\hline \multirow{2}{*}{ Position } & \multicolumn{2}{|l|}{$1^{b}$} & \multicolumn{2}{|l|}{$2^{b}$} & \multicolumn{2}{|l|}{$3^{c}$} \\
\hline & $\delta_{H}$ & бc, type & $\delta_{H}$ & бc, type & $\delta_{\mathbf{H}}$ & бc, type \\
\hline 1 & & & & 161.3, C & & $158.1, \mathrm{C}$ \\
\hline 2 & $5.08, \mathrm{~m}$ & $86.5, \mathrm{CH}$ & & & & \\
\hline 3 & $\begin{array}{l}3.04, \mathrm{~m}^{\mathrm{d}} \\
2.90, \mathrm{dd}(15.2,7.2)\end{array}$ & $35.2, \mathrm{CH}_{2}$ & & $150.8, \mathrm{C}$ & & $138.4, \mathrm{C}$ \\
\hline 4 & $6.59, \mathrm{~d}(7.6)$ & $117.9, \mathrm{CH}$ & $7.49, \mathrm{~s}$ & $108.3, \mathrm{CH}$ & & 136.9, C \\
\hline $4 a$ & & & & $136.5, \mathrm{C}$ & & $128.9, \mathrm{C}$ \\
\hline 5 & $6.32, \mathrm{~d}(7.6)$ & $101.6, \mathrm{CH}$ & $6.50, \mathrm{~s}$ & $105.3, \mathrm{CH}$ & $7.16, \mathrm{~s}$ & $102.8, \mathrm{CH}$ \\
\hline 6 & & $150.1, \mathrm{C}$ & & 156.0, C & & 159.6. C \\
\hline 7 & & 131.1, C & & $135.9, \mathrm{C}$ & & 143.7, C \\
\hline 8 & & 143.2, C & & $143.5, \mathrm{C}$ & & $159.4, \mathrm{C}$ \\
\hline $8 \mathrm{a}$ & & & & $98.7, \mathrm{C}$ & & 107.2, C \\
\hline 9 & & 124.7, C & & & 7.80, ddd $(7.8,1.8,0.6)$ & $119.9, \mathrm{CH}$ \\
\hline $9 \mathrm{a}$ & & & & & & $120.8, \mathrm{C}$ \\
\hline 10 & & & & & $7.43, \operatorname{td}(7.2,1.2)$ & $125.5, \mathrm{CH}$ \\
\hline 11 & & & & & $7.51, \operatorname{td}(7.2,1.2)$ & $128.3, \mathrm{CH}$ \\
\hline 12 & & & & & $7.68, \mathrm{dd}(8.4,1.2)$ & $113.8, \mathrm{CH}$ \\
\hline $12 \mathrm{a}$ & & & & & & $155.4, \mathrm{C}$ \\
\hline $1^{\prime}$ & & $115.9, \mathrm{C}$ & & 119.6, C & & \\
\hline $2^{\prime}$ & & $157.5, \mathrm{C}$ & & 156.9, C & & \\
\hline $3^{\prime}$ & $6.29, \mathrm{~d},(2.4)$ & $103.4, \mathrm{CH}$ & $6.93, \mathrm{dd}(7.6,1.2)$ & $117.4, \mathrm{CH}$ & & \\
\hline $4^{\prime}$ & & $158.2, \mathrm{C}$ & 7.24, ddd $(8.0,7.6,1.6)$ & $131.6, \mathrm{CH}$ & & \\
\hline $5^{\prime}$ & $6.23, \mathrm{dd}(8.4,2.4)$ & $107.4, \mathrm{CH}$ & $6.95, \mathrm{dd}(8.0,1.2)$ & $120.7, \mathrm{CH}$ & & \\
\hline $6^{\prime}$ & $6.92, \mathrm{~d}(8.4)$ & $132.8, \mathrm{CH}$ & $7.79, \mathrm{dd}(8.0,1.6)$ & $128.6, \mathrm{CH}$ & & \\
\hline $7^{\prime}$ & $\begin{array}{l}3.04, \mathrm{~m}^{\mathrm{d}} \\
2.81, \mathrm{dd}(14.0,8.0)\end{array}$ & $36.6, \mathrm{CH}_{2}$ & & & & \\
\hline $7-\mathrm{OCH}_{3}$ & & & $3.90, \mathrm{~s}(3 \mathrm{H})$ & $60.9, \mathrm{CH}_{3}$ & 3.94, s (3H) & $62.3, \mathrm{CH}_{3}$ \\
\hline $8-\mathrm{OCH}_{3}$ & & & & & $3.97, \mathrm{~s}(3 \mathrm{H})$ & $62.6, \mathrm{CH}_{3}$ \\
\hline $\mathrm{OCH}_{2} \mathrm{O}-$ & $5.86, \mathrm{~s}(2 \mathrm{H})$ & $102.3, \mathrm{CH}_{2}$ & & & & \\
\hline
\end{tabular}

${ }^{a}$ The assignments were based on COSY, HSQC, and HMBC experiments; ${ }^{b}{ }^{1} \mathrm{H}(400 \mathrm{MHz})$ and ${ }^{13} \mathrm{C}(100 \mathrm{MHz})$ NMR were measured in methanol- $d_{4} ;{ }^{c}{ }^{1} \mathrm{H}(600 \mathrm{MHz})$ and ${ }^{13} \mathrm{C}(150 \mathrm{MHz}) \mathrm{NMR}$ were measured in acetone- $d_{6}$; d Signals overlapping.

The HMBC correlations between H-3/C-8 and C-9, H-4/C-3 and C-9, and H-5/C-8 and C-9 (Figure 2) indicated that the 1,2,3,4-tetrasubstituted aromatic ring was connected to the 2,3-dihydrofuran ring. A COSY cross peak between H-2/H-7' and the HMBC correlations between H-7'/C-1', C-2', and C-6' (Figure 2) suggested that the 1,2,4-trisubstituted aromatic ring and 2,3-dihydrobenzofuran was connected at C-7'. 


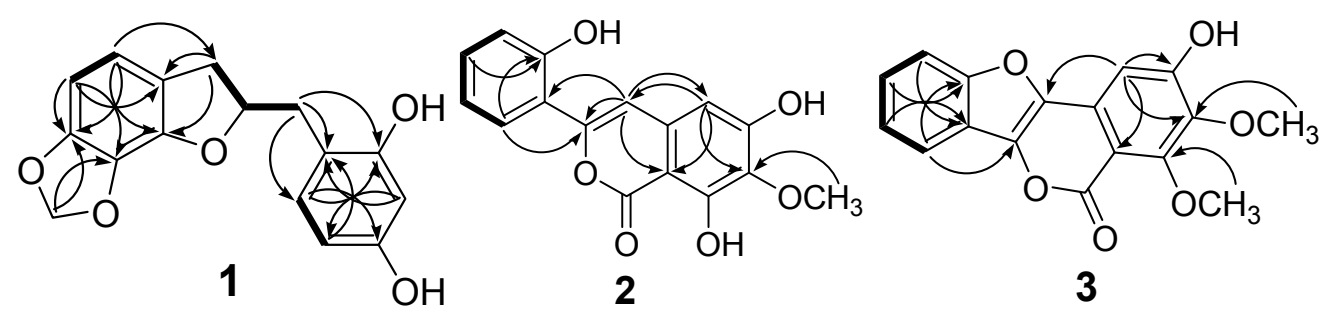

Figure 2. Key COSY $(-)$ and HMBC $(\rightarrow)$ correlations of $\mathbf{1}-\mathbf{3}$.

The skeleton of 1 was established as 2-benzyl-2,3-dihydrobenzofuran. Additionally, the position of the methylenedioxy group was confirmed by the HMBC correlations to C- 6 and C-7. The configuration of 1 was determined to be $2 R$ by comparing the optical rotation $[\alpha]_{\mathrm{D}}^{25} 254.9(c 0.07, \mathrm{MeOH})$ of 1 to the literature data [25]. Thus, compound $\mathbf{1}$ was established as (2R)-(2',4'-dihydroxybenzyl)-6,7methylenedioxy-2,3-dihydrobenzofuran.

Compound 2 was isolated as a yellow amorphous powder. The molecular formula was calculated as $\mathrm{C}_{16} \mathrm{H}_{12} \mathrm{O}_{6}$ from the analysis of its HRESIMS $\left(\mathrm{m} / z 323.05252[\mathrm{M}+\mathrm{Na}]^{+}\right.$, calcd. for 323.05261), indicating eleven degrees of unsaturation. The IR spectrum indicated the presence of hydroxy $\left(3386 \mathrm{~cm}^{-1}\right)$, carbonyl $\left(1662 \mathrm{~cm}^{-1}\right)$, and aromatic $\left(1609\right.$ and $\left.1576 \mathrm{~cm}^{-1}\right)$ functionalities. From the ${ }^{13} \mathrm{C}-\mathrm{NMR}$ and DEPT spectra, one methoxy, six aromatic/olefinic methines, five oxygenated aromatic carbons, three aromatic/olefinic quaternary carbons, and one ester carbon were observed (Table 1). Two proton signals at $\delta_{\mathrm{H}} 7.49(\mathrm{~s}, \mathrm{H}-4)$ and $6.50(\mathrm{~s}, \mathrm{H}-5)$ and four proton signals of the 1,2-disubstituted aromatic ring at $\delta_{\mathrm{H}}$ 6.93 (dd, $\left.J=7.6,1.2, \mathrm{H}^{\prime} 3^{\prime}\right), 7.24$ (ddd, $J=8.0,7.6,1.6, \mathrm{H}-4$ '), 6.95 (dd, $J=8.0,1.2, \mathrm{H}-5^{\prime}$ ), and 7.79 (dd, $\left.J=8.0,1.6, \mathrm{H}^{6} 6^{\prime}\right)$ were observed in the ${ }^{1} \mathrm{H}-\mathrm{NMR}$ spectrum. The ${ }^{13} \mathrm{C}-\mathrm{NMR}$ signals along with the HMBC correlations between H-4/C-3 ( $\left.\delta_{\mathrm{C}} 150.8\right), \mathrm{C}-5$ ( $\left.\delta_{\mathrm{C}} 105.3\right), \mathrm{C}-8 \mathrm{a}\left(\delta_{\mathrm{C}} 98.7\right)$, and H-5/C-4 $\left(\delta_{\mathrm{C}} 108.3\right), \mathrm{C}-8 \mathrm{a}$ (Figure 2) indicated the presence of an isocoumarin moiety formed by connecting the penta-substituted aromatic ring and the 2-pyrone ring systems [26]. The methoxy group $\left(\delta_{\mathrm{H}} 3.90, \mathrm{~s}, 3 \mathrm{H}\right)$ was connected at C-7 as indicated by the HMBC correlations of $\mathrm{H}-5 / \mathrm{C}-7$ and $\mathrm{OCH}_{3} / \mathrm{C}-7$ as well as by the absence of NOE correlation to H-5. An additional 1,2-disubstituted aromatic ring was confirmed and found to be connected to C-3 of the isocoumarin moiety as suggested by the HMBC correlations between H-4/C-3, C-1' and H-6'/C-3 (Figure 2). Thus, compound 2 was established as 3-(2'-hydroxyphenyl)-6,8dihydroxy-7-methoxyisocoumarin.

Compound 3 was isolated as a white amorphous powder. The molecular formula was calculated as $\mathrm{C}_{17} \mathrm{H}_{12} \mathrm{O}_{6}$ from the analysis of its HRESIMS $\left(\mathrm{m} / z\right.$ 335.05254 $[\mathrm{M}+\mathrm{Na}]^{+}$, calcd. for 335.05261), indicating 12 degrees of unsaturation. The IR spectrum indicated the presence of hydroxy $\left(3350 \mathrm{~cm}^{-1}\right)$, carbonyl $\left(1708 \mathrm{~cm}^{-1}\right)$, and aromatic $\left(1594 \mathrm{~cm}^{-1}\right)$ functionalities. From the ${ }^{13} \mathrm{C}-\mathrm{NMR}$ and DEPT spectra, two methoxy groups, five methines, six oxygenated aromatic carbons, one ester carbon, and three aromatic/olefinic quaternary carbons were observed. The NMR data of $\mathbf{3}$ suggested a double bond, two aromatic rings, and an ester functionality in the skeleton, similar to the functional groups in $\mathbf{2}$. Compound 3 showed signals at $\delta_{\mathrm{H}} 7.16$ (s, H-5), $\delta_{\mathrm{C}} 102.8$ (CH-5), 159.6 (C-6), 143.7 (C-7), and $159.4(\mathrm{C}-8)$, three quaternary carbons at $\delta_{\mathrm{C}} 138.4(\mathrm{C}-3), 136.9(\mathrm{C}-4)$, and $128.9(\mathrm{C}-4 \mathrm{a})$, a high field aromatic carbon at $\delta \mathrm{C}$ 107.2 (C-8a), and an unusual ester carbon signal at $\delta \mathrm{c} 158.1$ (C-1), along with the HMBC correlations between $\mathrm{H}-5 / \mathrm{C}-4, \mathrm{C}-6, \mathrm{C}-7$, and C-8a (Figure 2), indicating the presence of the isocoumarin moiety similar to 2, except for an additional substitution at C-4. The ${ }^{1} \mathrm{H}-\mathrm{NMR}$ signals at $\delta_{\mathrm{H}} 7.80$ (ddd, $J=7.8$, 
1.8, 0.6, H-9), 7.43 (td, $J=7.2,1.2, \mathrm{H}-10), 7.51$ (td, $J=7.2,1.2, \mathrm{H}-11)$, and 7.68 (dd, $J=8.4,1.2, \mathrm{H}-12)$ indicated the presence of a 1,2-disubstituted aromatic ring. Moreover, the one degree of unsaturation more than 2 and the HMBC correlations between H-9/C-3 and C-12a and H-12/C-9a (Figure 2), suggested the presence of a benzofuran moiety. This proposal was further confirmed by comparing the NMR data of $\mathbf{3}$ with the reported literature [27]. Through connecting the two moieties, the scaffold of $\mathbf{3}$ was established as a benzofuroisocoumarin [28]. The position of the methoxy groups $\left(\delta_{\mathrm{H}} 3.94\right.$ and 3.97) were confirmed by the HMBC correlations to C-7 and C-8, respectively, as well as by the absence of any NOESY cross peak to H-5. Based on the aforementioned discussion, compound $\mathbf{3}$ was established as 6-hydroxy-7,8-dimethoxy-benzofuroisocoumarin, and named platyphyllarin C.

2-Benzylbenzofuran [5], phenylisocoumarin [29], and benzofuroisocoumarin [12] structures are uncommon in Nature. 2-Benzyl-2,3-dihydrobenzofuran structures such as compound $\mathbf{1}$, have never been reported from natural sources. Compound $\mathbf{2}$ is only the second example of a natural 3-phenyl-isocoumarin and $\mathbf{3}$ is the third example of a natural benzofuroisocoumarin.

\subsection{The Binding Activity of the Isolates to ER $\alpha$ and/or $\beta$}

Due to the limitated sample availability of some of the isolates, compounds $\mathbf{3}, \mathbf{4}, \mathbf{9}, \mathbf{1 0}, \mathbf{1 3}-\mathbf{1 5}, \mathbf{1 9}$, and 20 were selected to test their binding potential to the estrogen-receptors $\alpha$ and $\beta$ at several concentrations $(1 \mathrm{nM}-100 \mu \mathrm{M})$. The basic medium without the addition of the tested compounds (basal) and $17 \beta$-estradiol (E2, $100 \mathrm{nM})$ were used as the blank and positive control, respectively. Cell viability was determined by MTT assay, and the estrogenic activity was evaluated using the SEAP reporter assay system. Both assays were expressed as a percentage based on the basal control, which SEAP\% and MTT\% of blank were defined as 100\% (Figures 3 and 4). For the SEAP\% of ER $\alpha$, compounds 4, 9, 10, 13, and 15 displayed significant binding activity. After excluding the false results from the cell survival ratio, 3-O-methylquercetin (10) and 6- $C$-methylquercetin-3-methyl ether (13) exhibited the most potent effect in a dose-dependent manner.

Moreover, the new compound, platyphyllarin C (3), showed weak activity to the ER $\alpha$ binding assay, and exhibited weak toxicity to MCF-7 cells at high concentration, 10 and $100 \mu \mathrm{M}$ (Figure 3). In the ER $\beta$ binding assay, all tested isolates exhibited weak to strong activities in a dose-dependent manner. Among the evaluated compounds, flavonoids 9, 10 and, 13, and homoisoflavones 19 and 20 exhibited high binding ability in SEAP/MTT\% (Figure 4).

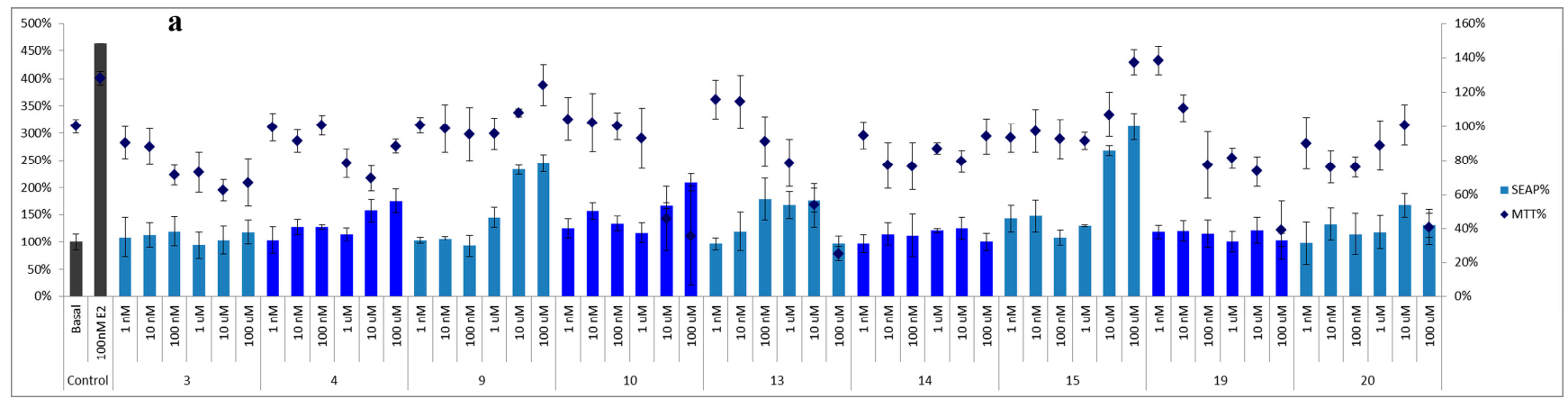

Figure 3. Cont. 


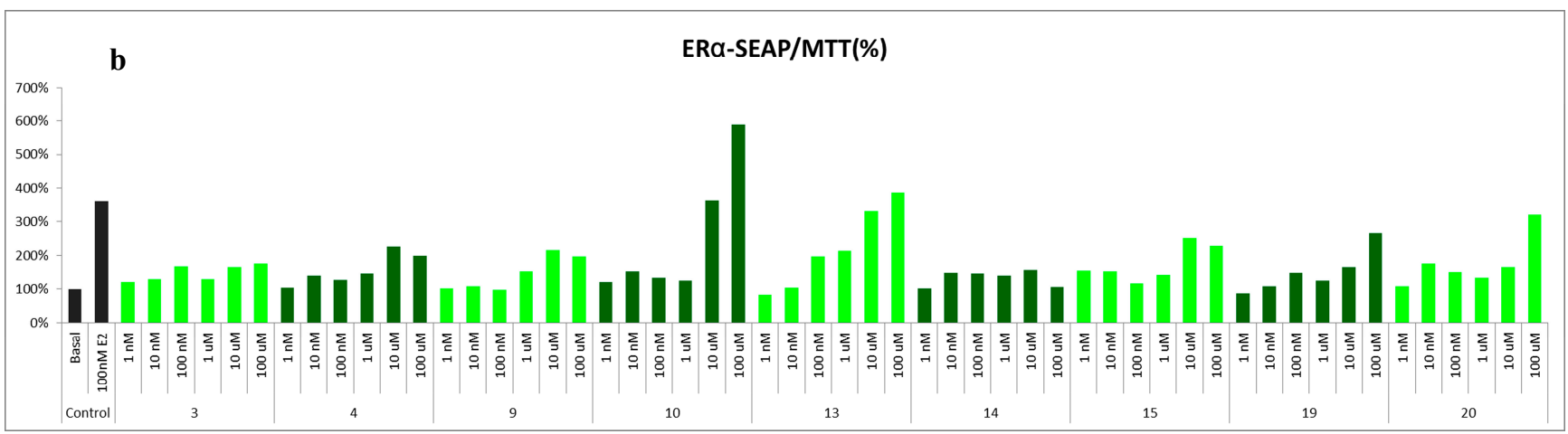

Figure 3. Binding activity to estrogen-receptor alpha (ER $\alpha$ ). (a) The SEAP\% of ER $\alpha$ activity and the MTT\% of MCF-7 cells were presented in percentage, respectively; (b) The SEAP/MTT\% was calculated as the final estrogenic data of ER $\alpha$ to avoid false results from cytotoxicity.

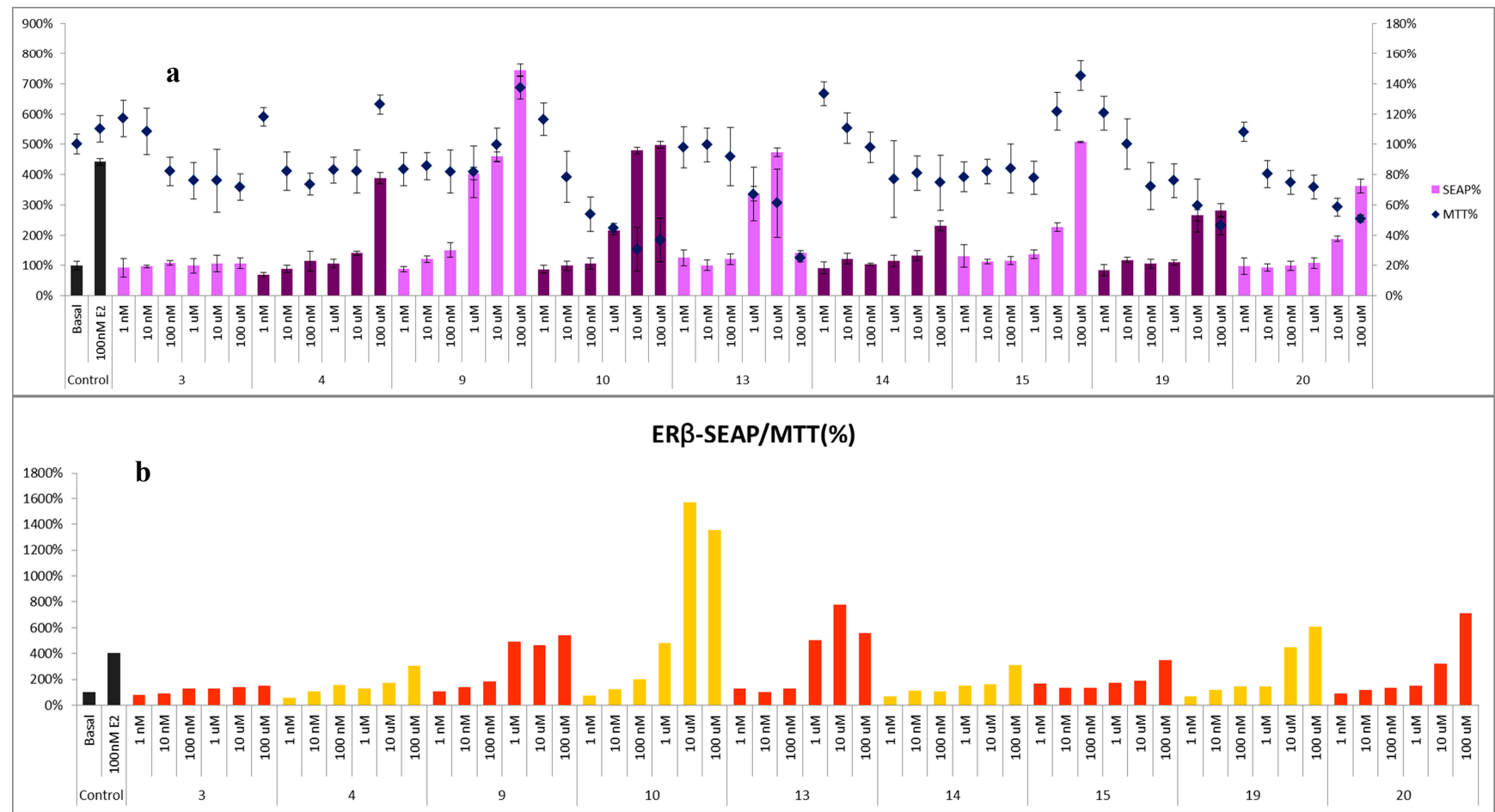

Figure 4. Binding activity to estrogen-receptor beta (ER $\beta)$. (a) The SEAP\% of ER $\beta$ activity and the MTT\% of MCF-7 cells were presented in percentage, respectively; (b) The SEAP/MTT\% was calculated as the final estrogenic data of ER $\beta$ to avoid false results from cytotoxicity.

\section{Experimental Section}

\subsection{General Procedures}

Optical rotations were measured with a JASCO P-2000 polarimeter (JASCO Inc., Tokyo, Japan). IR spectra were measured on a PerkinElmer System 2000 FT-IR spectrophotometer (PerkinElmer Inc., Waltham, MA, USA). ${ }^{1} \mathrm{H}$ and ${ }^{13} \mathrm{C}-\mathrm{NMR}$ spectra were recorded on Varian VNMRS $600 \mathrm{MHz}$ FT-NMR, Varian Unity-plus 400 MHz FT-NMR (Varian Inc., Palo Alto, CA, USA), or JNM-ECS 400 (JEOL Ltd., 
Tokyo, Japan) NMR spectrometers. Chemical shifts are reported in parts per million $(\delta)$, and coupling constants $(J)$ are expressed in hertz. LRESIMS was measured on a Waters micromass ZQ mass spectrometer (Waters Corporation, Milford, MA, USA). HRESIMS were measured on a Bruker Daltonics APEX II 30e mass spectrometer (Bruker Instruments, Billerica, MA, USA). Silica gel (Kieselgel 60, 70-230 and 230-400 mesh, Merck KGaA, Darmstadt, Germany), $\mathrm{C}_{18}$ reversed phase silica gel (100 A, 230-400 mesh, Merck KGaA), and Sephadex LH-20 gel (Pharmacia Fine Chemicals AB, Uppsala, Sweden) were used for column chromatography. TLC was carried out using silica gel (Kieselgel 60, F254, Merck KGaA) and RP-18 ( $\mathrm{F}_{254 s}$, Merck KGaA) precoated plates and compounds were detected with $50 \% \mathrm{H}_{2} \mathrm{SO}_{4}$ followed by heating on a hot plate. HPLC analyses were performed with a Shimadzu LC-10AT (Shimadzu Inc., Kyoto, Japan) pump interface equipped with a Shimadzu SPD-10A UV-Vis detector using ODS (Thermo Hypersil, $250 \times 4 \mathrm{~mm}$; Thermo Hypersil, $250 \times 10 \mathrm{~mm}$, Thermo Fisher Scientific Inc., Rockford, IL, USA) and Luna ${ }^{\circledR}$ Phenyl-Hexyl column (5 $\mu \mathrm{m}, 250 \times 10 \mathrm{~mm}$, Phenomenex Inc., Torrance, CA, USA) columns. ACS grade $n$-hexane, dichloromethane, ethyl acetate, acetone, methanol, ammonia and 95\% sulfuric acid were purchased from ECHO Chemical Co., Ltd. (Miaoli, Taiwan). HPLC grade acetonitrile, methanol, $\mathrm{CDCl}_{3}$, acetone- $d_{6}, \mathrm{CD}_{3} \mathrm{OD}$, and $\mathrm{C}_{5} \mathrm{D}_{5} \mathrm{~N}$ were obtained from Merck KGaA. Water for chromatographic separation was purified by a Milli-Q water advantage A 10 water system (Merck Millipore, Temecula, CA, USA).

\subsection{Plant Material}

The plant material was collected in July 2012 from Taichung County, Taiwan, and was identified by a specialist in herbal medicine, Dr. Ming-Hong Yen. A voucher specimen (LP011) was deposited at the Graduate Institute of Natural Products, Kaohsiung Medical University, Kaohsiung, Taiwan. The fresh aerial parts were crushed using a mill (Rong Tsong, Taichung City, Taiwan) before extraction.

\subsection{Extraction and Isolation}

The fresh aerial parts of L. platyphylla $(25 \mathrm{~kg})$ were extracted three times with $95 \% \mathrm{EtOH}(60 \mathrm{~L})$ at room temperature for $24 \mathrm{~h}$. The ethanolic extract (1894.1 g) was concentrated in vacuo, suspended in water and further partitioned into $n$-hexane, ethyl acetate, and $n-\mathrm{BuOH}$, respectively. The EtOAc layer (76.8 g) was subjected to Sephadex LH-20 column chromatography $(\mathrm{CC}, 57 \times 4.5 \mathrm{~cm})$ and eluted successively with $\mathrm{CH}_{2} \mathrm{Cl}_{2}-\mathrm{EtOAc}-\mathrm{MeOH}(1: 1: 6, v / v$, repeated 10 times) to afford nine fractions. Fraction 4 was subjected to Sephadex LH-20 CC with $\mathrm{CH}_{2} \mathrm{Cl}_{2}-\mathrm{EtOAc}-\mathrm{MeOH}(1: 1: 6, v / v)$ and further purified using reversed phase (RP) $\mathrm{C}_{18} \mathrm{HPLC}$ eluted with $\mathrm{MeOH}-\mathrm{H}_{2} \mathrm{O}(40: 60, v / v)$ to obtain 5 (5.1 mg). Fraction 6 was further chromatographed using RP-C ${ }_{18} \mathrm{CC}$ and eluted with gradient $\mathrm{MeOH}-\mathrm{H}_{2} \mathrm{O}(10: 90$ $\rightarrow 60: 40$ and $100 \% \mathrm{MeOH}$ for wash, $v / v$ ) to yield 14 subfractions, including pure compound 15 (391.9 mg, fr. 6-6). Subfraction 6-7 was isolated using RP- $\mathrm{C}_{18} \mathrm{CC}$ with $\mathrm{MeOH}-\mathrm{H}_{2} \mathrm{O}(45: 55, v / v)$ to get $14(25.6 \mathrm{mg})$ and $16(0.9 \mathrm{mg})$. Subfraction 6-9 was subjected to RP-C ${ }_{18}$ HPLC eluted with $\mathrm{MeOH}-\mathrm{H}_{2} \mathrm{O}(50: 50, v / v)$ to yield 18 (2.0 mg). Subfraction 6-10 was separated using $\mathrm{RP}-\mathrm{C}_{18} \mathrm{CC}$ with $\mathrm{MeCN}-\mathrm{H}_{2} \mathrm{O}(25: 75 \rightarrow 40: 60$, $v / v)$ and was further purified by RP- $\mathrm{C}_{18}$ HPLC with $\mathrm{MeCN}-\mathrm{H}_{2} \mathrm{O}(35: 65, v / v)$ to obtain $9(10.3 \mathrm{mg})$ and 10 (32.9 mg). Subfraction 6-11 was subjected to silica gel $\mathrm{CC}$ and eluted with gradient $\mathrm{CH}_{2} \mathrm{Cl}_{2}-\mathrm{MeOH}$ $(35: 1 \rightarrow 25: 1, v / v)$ to yield five subfractions. Subfraction 6-11-1 was further purified by RP-C 18 HPLC with $\mathrm{MeOH}-\mathrm{H}_{2} \mathrm{O}(60: 40, v / v)$ to yield $3(3.2 \mathrm{mg})$ and 4 (4.0 mg). Subfraction 6-11-2 was separated using 
RP-C ${ }_{18} \mathrm{CC}$ with $\mathrm{MeOH}-\mathrm{H}_{2} \mathrm{O}(30: 80 \rightarrow 80: 20, v / v)$ and was further purified by RP-C 18 HPLC with $\mathrm{MeOH}-\mathrm{H}_{2} \mathrm{O}(60: 40, v / v)$ to obtain $1(0.8 \mathrm{mg}), \mathbf{6}(1.0 \mathrm{mg}), 7(0.5 \mathrm{mg}), \mathbf{8}(0.6 \mathrm{mg})$, and a mixture of 11 and 12 (1.2 mg). Subfraction 6-11-4 was subjected to RP-C $\mathrm{C}_{18} \mathrm{HPLC}$ with $\mathrm{MeOH}-\mathrm{H}_{2} \mathrm{O}(60: 40, v / v)$ to yield $13(25.0 \mathrm{mg})$ and $20(4.1 \mathrm{mg})$. Subfraction 6-12 was isolated using silica gel CC eluted with gradient $\mathrm{CH}_{2} \mathrm{Cl}_{2}-\mathrm{MeOH}(20: 1 \rightarrow 15: 1, v / v)$ and was further purified by RP-C 18 HPLC eluted with $\mathrm{MeCN}-\mathrm{H}_{2} \mathrm{O}(45: 55, v / v)$ to yield $2(1.5 \mathrm{mg})$ and $19(7.3 \mathrm{mg})$. Fraction 7 was separated by RP-C ${ }_{18} \mathrm{CC}$ eluted with gradient $\mathrm{MeOH}-\mathrm{H}_{2} \mathrm{O}(40: 60 \rightarrow 60: 40$ and 100\% MeOH for wash, $v / v)$ to afford $17(6.4 \mathrm{mg})$.

\subsection{Experimental Data of the New Compounds 1-3}

Compound 1: Light-yellow amorphous powder; $[\alpha]_{\mathrm{D}}^{25} 254.9(c 0.07, \mathrm{MeOH}) ; \mathrm{UV}(\mathrm{MeOH}) \lambda_{\max }(\log \varepsilon)$ 212 (4.75), 280 (3.77) nm; IR $v_{\max }^{\text {neat }} 3397(\mathrm{OH}), 1619,1600$ (aromatic $\mathrm{C}=\mathrm{C}$ bond), 1466, 1252, 1057, $1019 \mathrm{~cm}^{-1}$; ${ }^{1} \mathrm{H}-\mathrm{NMR}$ and ${ }^{13} \mathrm{C}-\mathrm{NMR}\left(\mathrm{MeOH}-d_{4}\right)$ : see Table 1; ESIMS found $m / z 287[\mathrm{M}+\mathrm{H}]^{+}$and 309 $[\mathrm{M}+\mathrm{Na}]^{+}$; HR-ESIMS found $m / z$ 309.07307 [M $\left.+\mathrm{Na}\right]^{+}$(calcd for $\mathrm{C}_{16} \mathrm{H}_{14} \mathrm{O}_{5} \mathrm{Na}$ : 309.07334).

Compound 2: Yellow amorphous powder; UV (MeOH) $\lambda_{\max }(\log \varepsilon) 217$ (4.10), 260 (4.25), 350 (3.97) nm; IR $v_{\max }^{\text {neat }} 3386(\mathrm{OH}), 1662(\mathrm{C}=\mathrm{O}), 1609,1576$ (aromatic $\mathrm{C}=\mathrm{C}$ bond), 1452, 1260, $1094 \mathrm{~cm}^{-1}$; ${ }^{1} \mathrm{H}-\mathrm{NMR}$ and ${ }^{13} \mathrm{C}-\mathrm{NMR}\left(\mathrm{MeOH}-d_{4}\right)$ : see Table 1; ESIMS found $m / z 301[\mathrm{M}+\mathrm{H}]^{+}$and $323[\mathrm{M}+\mathrm{Na}]^{+}$; HR-ESIMS found $m / z 323.05252[\mathrm{M}+\mathrm{Na}]^{+}$(calcd for $\mathrm{C}_{16} \mathrm{H}_{12} \mathrm{O}_{6} \mathrm{Na}: 323.05261$ ).

Compound 3: White amorphous powder; UV (MeOH) $\lambda_{\max }(\log \varepsilon) 214$ (3.32), 267 (3.60), 314 (3.37), $351(3.21) \mathrm{nm}$; IR $v_{\max }^{\text {neat }}: 3350(\mathrm{OH}), 1708(\mathrm{C}=\mathrm{O}), 1594$ (aromatic $\mathrm{C}=\mathrm{C}$ bond), 1369, 1262, 1203, $986 \mathrm{~cm}^{-1}$; ${ }^{1} \mathrm{H}-\mathrm{NMR}$ and ${ }^{13} \mathrm{C}-\mathrm{NMR}$ (Aceton- $d_{6}$ ): see Table 1; ESIMS found $m / z 313[\mathrm{M}+\mathrm{H}]^{+}$; HR-ESIMS found $m / z 335.05254[\mathrm{M}+\mathrm{Na}]^{+}$(calcd for $\mathrm{C}_{17} \mathrm{H}_{12} \mathrm{O}_{6} \mathrm{Na}: 335.05261$ ).

\subsection{Bioassay Procedure-Estrogenic Activity}

The estrogenic activity was determined through adapting the method described by Lai et al. (2011) [30]. The assay was done using SEAP (secreted alkaline phosphatase) reporter gene assay system. Human breast adenocarcinoma cells MCF-7 obtained from Bioresource Collection and Research Center were cultured in phenol-red free minimum essential medium Eagle (MEM) supplemented with dextran-charcoal treated serum, 2 mM L-glutamine, 10\% foetal bovine serum (GIBCO BRL, Gaithersburg, MD, USA), penicillin, and streptomycin. The cells were incubated in an atmosphere of $5 \% \mathrm{CO}_{2}$ at $37{ }^{\circ} \mathrm{C} ; 0.2 \mu \mathrm{g}$ of pERE-TA-SEAP plasmid (Clontech, Palo Alto, CA, USA) were transfected into $2 \times 104$ cells in $100 \mu \mathrm{L}$ of growth medium per well and incubated for $6 \mathrm{~h}$. Cells were treated with samples of interest in growth medium for $48 \mathrm{~h}$. Aliquots of culture media were analyzed for secreted alkaline phosphatase activity using the Phospha-Light reporter chemiluminescence assay kit (Applied Biosystems, Foster City, CA, USA). The MTT colorimetric assay was performed on the cells for assessing their corresponding cytotoxicity. The estrogenic data were determined by the formula, final SEAP/MTT $\%=\mathrm{SEAP} /$ cell viability $\times 100 \%$, to avoid false results from cytotoxicity. Tests were done in triplicate. For the raw data please see supplementary data. The purity of tested compounds was more than $95 \%$. 


\section{Conclusions}

In the current investigation, the estrogenic activity of different fractions obtained from the ethanolic extract of L. platyphylla areal parts was evaluated. Bioassay-guided isolation of the most active fraction (EtOAc) led to the purification of one new 2-benzyl-2,3-dihydrobenzofuran 1, one new phenylisocoumarin $\mathbf{2}$, and one new benzofuroisocoumarin $\mathbf{3}$, along with seventeen known compounds. The spectroscopic analyses revealed that 1-3 structures possess unique skeletons which were rarely isolated from nature. 3-O-methylquercetin (10) and 6- $\mathrm{C}$-methylquercetin-3-methyl ether (13) exhibited the most potent estrogenic effect in a dose-dependent manner as demonstrated by the SEAP reporter assay system. Moreover, flavonoids 9, 10 and, 13, and homoisoflavones 19 and 20 expressed high binding ability in the ER $\beta$ binding assay. Selective binding to ER $\beta$ receptor is an interesting phenomenon from the therapeutic point of view because such binding mimics the beneficial effect of estrogen without the side effects associated with unspecific receptor targeting.

\section{Supplementary Materials}

1D and 2D NMR spectra, HR-ESIMS of the new isolates and the raw data of the estrogenic activity can be found in the Supplementary materials at: http://www.mdpi.com/1420-3049/20/04/6844/s1.

\section{Acknowledgments}

The authors would like to acknowledge the grants from the Ministry of Science and Technology of Taiwan (MOST 101-2325-B-039-004; 102-2628-B-037-003-MY3; MOST 102-2911-I-002-303; MOST 103-2911-I-002-303; MOST 104-2911-I-002-302; MOST 104-2911-I-037-501). This work was also supported by the Excellence for Cancer Research Center Grant, the Ministry of Health and Welfare, Executive Yuan, Taipei, Taiwan (MOHW104-TDU-B-212-124-003), National Health Research Institutes of Taiwan (NHRI-EX104-10241BI), and the grant for Health and Welfare Surcharge of Tobacco Products and Kaohsiung Medical University "Aim for the Top Universities Grant, grant No. KMU-TP103, and in part from the grant from Chinese Medicine Research Center, China Medical University, Taiwan (the Ministry of Education, the Aim for the Top University Plan). The authors would like to thank the Center for Research Resources and Development (CRRD), Kaohsiung Medical University for the technical supports and services in LC-MS and NMR analyses.

\section{Author Contributions}

Y.-C. Tsai and C.-C. Hsu did the major experimental work. Y.-C. Tsai, S.-Y. Chiang, W.-C. Lai, and F.-R. Chang conceived the project and designed the experiments. S.-Y. Chiang and M.-H. Yen collected and identified L. platyphylla. Y.-C. Tsai, M. El-Shazly, Chau-Chung Wu, Chin-Chung Wu, Y.-C. Wu, and F.-R. Chang drafted and revised the manuscript. All authors read and approved the final manuscript.

\section{Conflicts of Interest}

The authors declare no conflict of interest. 


\section{References}

1. Lee, J.H.; Choung, M.G. Identification and characterisation of anthocyanins in the antioxidant activity-containing fraction of Liriope platyphylla fruits. Food Chem. 2011, 127, 1686-1693.

2. Yang, S.O.; Ji, G.E. Inhibitory effects of ulmus parvifolia and liriope platyphylla wang et tang on histamine release from rat peritoneal mast cells. Food Sci. Biotechnol. 2006, 15, 363-368.

3. Yu, B.Y.; Qiu, S.X.; Zaw, K.; Xu, G.J.; Hirai, Y.; Shoji, J.; Fong, H.H.; Kinghorn, A.D. Steroidal glycosides from the subterranean parts of Liriope spicata var. Prolifera. Phytochemistry 1996, 43, 201-206.

4. Li, W.J.; Cheng, X.L.; Liu, J.; Lin, R.C.; Wang, G.L.; Du, S.S.; Liu, Z.L. Phenolic compounds and antioxidant activities of Liriope muscari. Molecules 2012, 17, 1797-1808.

5. Hu, Z.F.; Chen, L.L.; Qi, J.; Wang, Y.H.; Zhang, H.; Yu, B.Y. Two new benzofuran derivatives with anti-inflammatory activity from Liriope spicata var. Prolifera. Fitoterapia 2011, 82, 190-192.

6. Cheng, Z.H.; Wu, T.; Bligh, S.A.; Bashall, A.; Yu, B.Y. Cis-eudesmane sesquiterpene glycosides from liriope m uscari and ophiopogon j aponicus. J. Nat. Prod. 2004, 67, 1761-1763.

7. Wu, F.; Cao, J.; Jiang, J.; Yu, B.; Xu, Q. Ruscogenin glycoside (lm-3) isolated from Liriope muscari improves liver injury by dysfunctioning liver-infiltrating lymphocytes. J. Pharm. Pharmacol. 2001, $53,681-688$.

8. Kim, S.W.; Chang, I.M.; Oh, K.B. Inhibition of the bacterial surface protein anchoring transpeptidase sortase by medicinal plants. Biosci Biotechnol. Biochem. 2002, 66, 2751-2754.

9. Wang, H.C.; Wu, C.C.; Cheng, T.S.; Kuo, C.Y.; Tsai, Y.C.; Chiang, S.Y.; Wong, T.S.; Wu, Y.C.; Chang, F.R. Active constituents from liriope platyphylla root against cancer growth in vitro. Evid. Based Complement. Alternat. Med. 2013, 2013.

10. Bai, X.; Chen, X.; Liu, Y.; Tian, L.; Zhou, Q.; Liu, S.; Fang, J.; Chen, J. Effects of water extract and crude polysaccharides from Liriope spicata var. Prolifera on insr/irs-1/pi3k pathway and glucose metabolism in mice. J. Ethnopharmacol. 2009, 125, 482-486.

11. Hur, J.; Lee, P.; Kim, J.; Kim, A.J.; Kim, H.; Kim, S.Y. Induction of nerve growth factor by butanol fraction of Liriope platyphylla in c6 and primary astrocyte cells. Biol. Pharm. Bull. 2004, 27, $1257-1260$.

12. Tsai, Y.C.; Chiang, S.Y.; El-Shazly, M.; Wu, C.C.; Beerhues, L.; Lai, W.C.; Wu, S.F.; Yen, M.H.; Wu, Y.C.; Chang, F.R. The oestrogenic and anti-platelet activities of dihydrobenzofuroisocoumarins and homoisoflavonoids from liriope platyphylla roots. Food Chem. 2013, 140, 305-314.

13. Lee, S.Y.; Kim, K.H.; Lee, I.K.; Lee, K.H.; Choi, S.U.; Lee, K.R. A new flavonol glycoside from Hylomecon vernalis. Arch. Pharm. Res. 2012, 35, 415-421.

14. Veitch, N.C.; Sutton, P.S.; Kite, G.C.; Ireland, H.E. Six new isoflavones and a 5-deoxyflavonol glycoside from the leaves of ateleia herbert-smithii. J. Nat. Prod. 2003, 66, 210-216.

15. Ryu, Y.B.; Kim, J.H.; Park, S.J.; Chang, J.S.; Rho, M.C.; Bae, K.H.; Park, K.H.; Lee, W.S. Inhibition of neuraminidase activity by polyphenol compounds isolated from the roots of Glycyrrhiza uralensis. Bioorg. Med. Chem. Lett. 2010, 20, 971-974.

16. Ribeiro, D.; Freitas, M.; Tomé, S.M.; Silva, A.M.; Porto, G.; Fernandes, E. Modulation of human neutrophils' oxidative burst by flavonoids. Eur. J. Med. Chem. 2013, 67, 280-292. 
17. Liao, C.R.; Kuo, Y.H.; Ho, Y.L.; Wang, C.Y.; Yang, C.S.; Lin, C.W.; Chang, Y.S. Studies on cytotoxic constituents from the leaves of elaeagnus oldhamii maxim. In non-small cell lung cancer a549 cells. Molecules 2014, 19, 9515-9534.

18. Yamauchi, K.; Mitsunaga, T.; Inagaki, M.; Suzuki, T. Synthesized quercetin derivatives stimulate melanogenesis in b16 melanoma cells by influencing the expression of melanin biosynthesis proteins mitf and p38 mapk. Bioorg. Med. Chem. 2014, 22, 3331-3340.

19. Wang, J.; Gao, H.; Zhao, J.; Wang, Q.; Zhou, L.; Han, J.; Yu, Z.; Yang, F. Preparative separation of phenolic compounds from halimodendron halodendron by high-speed counter-current chromatography. Molecules 2010, 15, 5998-6007.

20. Ibewuike, J.C.; Ogundaini, A.O.; Ogungbamila, F.O.; Martin, M.T.; Gallard, J.F.; Bohlin, L.; Païs, M. Piliostigmin, a 2-phenoxychromone, and c-methylflavonols from Piliostigma thonningii. Phytochemistry 1996, 43, 687-690.

21. Luyen, B.T.T.; Tai, B.H.; Thao, N.P.; Eun, K.J.; Cha, J.Y.; Xin, M.J.; Lee, Y.M.; Kim, Y.H. Anti-inflammatory components of Euphorbia humifusa willd. Bioorg. Med. Chem. Lett. 2014, 24, 1895-1900.

22. Stark, T.; Bareuther, S.; Hofmann, T. Sensory-guided decomposition of roasted cocoa nibs (Theobroma cacao) and structure determination of taste-active polyphenols. J. Aagric. Food Chem. 2005, 53, 5407-5418.

23. Fico, G.; Rodondi, G.; Flamini, G.; Passarella, D.; Tomé, F. Comparative phytochemical and morphological analyses of three italian primula species. Phytochemistry 2007, 68, 1683-1691.

24. Nguyen, A.T.; Fontaine, J.; Malonne, H.; Duez, P. Homoisoflavanones from Disporopsis aspera. Phytochemistry 2006, 67, 2159-2163.

25. Ortega, N.; Urban, S.; Beiring, B.; Glorius, F. Ruthenium nhc catalyzed highly asymmetric hydrogenation of benzofurans. Angew. Chem. Int. Ed. 2012, 51, 1710-1713.

26. Shahzad, S.A.; Venin, C.; Wirth, T. Diselenide-and disulfide-mediated synthesis of isocoumarins. Eur. J. Org. Chem. 2010, 2010, 3465-3472.

27. Ghosh, S.; Banerjee, I.; Baul, S. Studies on oxygen heterocycles part 2: Synthesis of 2-arylcoumaranones and 2-phenylbenzofuran. Tetrahedron 1999, 55, 11537-11546.

28. Yamaguchi, S.; Uchiuzoh, Y.; Sanada, K. The synthesis of benzofuroquinolines. IX. A benzofuroisoquinolinone and a benzofuroisocoumarin. J. Heterocycl. Chem. 1995, 32, 419-423.

29. Charubala, R.; Guggisberg, A.; Hesse, M.; Schmid, H. Notiz über das natürliche auftreten von 3-phenylisocumarin. Helv. Chim. Acta 1974, 57, 1096-1097.

30. Lai, W.C.; Wang, H.C.; Chen, G.Y.; Yang, J.C.; Korinek, M.; Hsieh, C.J.; Nozaki, H.; Hayashi, K.I.; Wu, C.C.; Wu, Y.C. Using the per8: Gus reporter system to screen for phytoestrogens from Caesalpinia sappan. J. Nat. Prod. 2011, 74, 1698-1706.

Sample Availability: Samples of the compounds 1-20 are available from the authors.

(C) 2015 by the authors; licensee MDPI, Basel, Switzerland. This article is an open access article distributed under the terms and conditions of the Creative Commons Attribution license (http://creativecommons.org/licenses/by/4.0/). 